\title{
En busca de la diversidad: la poesía de Irlanda y Escocia en el siglo XX
}

\author{
Eva CRUZ YÁÑEZ \\ Universidad Nacional Autónoma de México
}

\begin{abstract}
Desde los años setentas del siglo pasado, las aportaciones del postestructuralismo, el posmodernismo, el poscolonialismo, el feminismo, así como de los estudios culturales y los nuevos estudios de traducción, han contribuido a cuestionar y a cambiar conceptos que se creían monolíticos y universales, tales como nación, cultura e identidad, dando lugar al multiculturalismo y a la afirmación de identidades específicas - nacionales, sexuales, étnicas, regionales - a partir de las nociones de otredad y diferencia. Asimismo, el fenómeno de la globalización, a pesar de su carácter hegemónico, transformó drásticamente las antiguas dicotomías como metrópoli/colonia, centro/periferia, norte/sur. Como resultado de estas transformaciones, los grupos colonizados, marginales o minoritarios se propusieron construir una identidad o representación cultural propia que había sido silenciada o distorsionada por la cultura dominante. Es el caso de Irlanda y Escocia, naciones que, con modalidades diferentes, han sufrido durante siglos la dominación inglesa. Las luchas por su autonomía o su independencia, así como sus intentos por construir una identidad política y cultural distinta a la inglesa, han sido una constante a lo largo de su historia, particularmente desde fines del siglo XIX a la fecha. En este artículo me propongo examinar la creación poética de algunos poetas irlandeses y escoceses, hombres y mujeres, nacidos en el siglo pasado, que reflejan estas preocupaciones en su práctica de escritura.
\end{abstract}

PALABRAS CLAVE: cultura hegemónica, globalización, multiculturalismo, otredad, diferencia, identidades específicas, diversidad.

Since the last three decades of the past century, the contributions of poststructuralism, postmodernism, postcolonialism, feminism, as well as those of cultural studies and the new studies in translation, have brought into question and radically transformed such concepts as nation, culture and identity, long considered monolithic and universal, thus giving rise to multiculturalism and the affirmation of specific identities - national, sexual, ethnic, regional - based on the notions of otherness and difference. Likewise, the phenomenon of globalization, in spite of its hegemonic effects, has drastically transformed the old metropolitan/colony, center/periphery, north/south dichotomies. As a result of these transformations, the colonized, marginal or minority groups set out to construct an identity or cultural representation of their own which had been silenced or distorted by the dominant culture. Such is the case of Ireland and Scotland, nations which for centuries have been subject, in different modalities, to English domination. The struggles for autonomy or independence, as well as their attempts at constructing 
a political and cultural identity distinct from the English, have been constant throughout their history, particularly from the end of the XIX century to the present. In this article I intend to examine the poetic work of some Irish and Scottish poets, both men and women, born in the last century, who reflect these concerns in their writing.

KEY WORDS: cultural hegemony, globalization, multi-culturalism, otherness, difference, specific identities, diversity.

La palabra "diversidad" a estas alturas del siglo XXI evoca de inmediato una serie de términos y conceptos que han sufrido transformaciones radicales a partir de las teorías y movimientos socioculturales de las últimas tres décadas del siglo pasado. La semiótica, el postestructuralismo, el poscolonialismo, el feminismo, el posmodernismo, los nuevos estudios de traducción y el auge de los estudios culturales, como sea que se definan, han contribuido radicalmente a cuestionar y a cambiar nuestras nociones de cultura e identidad que por mucho tiempo se vieron como conceptos monolíticos y universales desde la perspectiva de las potencias occidentales, es decir, los antiguos imperios de Europa y más tarde Estados Unidos. Paralelamente, los estudiosos de distintos campos se han dedicado a analizar los efectos de la globalización en un mundo cada vez más complejo.

Según Simon During, la globalización ha tenido efectos multidireccionales: por un lado, ha socavado la autonomía de los Estados-nación y reducido la intervención del Estado en la sociedad y la economía. Por el otro, ha transformado y debilitado drásticamente las antiguas dicotomías como metrópoli/colonia, centro/periferia, norte/ sur, propiciando que nuevas regiones se inventen a sí mismas y que surjan nuevos cosmopolitismos populares y de elite. De este modo concluye que la globalización es un fenómeno paradójico: no solamente unifica sino que también divide; uniforma y multiplica al mismo tiempo (During, 1993: 23). En este mismo sentido Susan Bassnett afirma que el gran debate de los noventas es la relación entre globalización, por un lado, y el surgimiento de nacionalismos, por el otro. La globalización es ciertamente un proceso creciente, pero también existe una resistencia masiva a este proceso (Bassnett y Lefevere, 1988: 133).

Estas afirmaciones sobre la globalización y sus efectos nos llevan a examinar el cambio radical de la noción de cultura, resultado en parte de este proceso simultáneo de integración y de división. En los primeros años de la década de los setentas distintos teóricos en diversas disciplinas comenzaron a cuestionar la idea de la cultura como universal y única y a considerarla como una forma de hegemonía con el fin de preservar el status quo. Como explica Terry Eagleton, no sin cierta ironía, existe un conflicto entre el concepto de Cultura, entendida como una forma de subjetividad universal con valores compartidos, y la cultura que "desde 1960 ha girado sobre su propio eje y ha empezado a significar prácticamente lo contrario. Ahora significa la afirmación de 
identidades específicas —nacionales, sexuales, étnicas, regionales — en vez de su superación" (2001: 64).

Este giro extremo que Eagleton reconoce en el significado de "cultura", con las consecuentes implicaciones políticas y sociales, es compartido por los exponentes de teorías como el postestructuralismo, el poscolonialismo, el feminismo, el deconstructivismo y demás ismos posmodernos: cultura es igual a la afirmación de una identidad específica. Homi K. Bhabha, el teórico poscolonialista, precisa: "Increasingly, the issue of cultural difference emerges at points of social crises, and the questions of identity that it raises are agonistic; identity is claimed either from a position of marginality or in an attempt at gaining the centre: in both senses, ex-centric" (1993: 195).

De este modo se puede decir que la resistencia a la globalización es una resistencia a la hegemonía y una afirmación de la diferencia que da lugar al multiculturalismo. En otras palabras, el rechazo a la noción monolítica de "cultura", como forma de resistencia a la dominación que implica la globalización, va aparejado a la afirmación de identidades diversas y plurales sustentadas en las nociones de "otredad" y "diferencia" propuestas por el postestructuralismo y el poscolonialismo, entre otros.

El feminismo ha contribuido también a cuestionar las nociones monolíticas de cultura e identidad, así como al desarrollo de políticas de identidad y representación cultural. En su libro Gender in Translation, Sherry Simon cita a la teórica feminista Gayatri Spivak, quien, basándose en el concepto derrideano de "différance", considera la diferencia de las mujeres como una entre una vasta gama de distintas presiones culturales, como raza, clase o nación. Esta comprensión y aceptación de la pluralidad de diferencias o culturas ha resultado en una priorización del concepto de "ubicación". De este modo, la identidad se entiende como un posicionamiento en el discurso y la historia. Es por eso que las teorías feministas han puesto énfasis en la naturaleza activa de las prácticas de representación, las cuales construyen posiciones para el sujeto y producen identidades (1996: 141).

De lo anteriormente expuesto se puede concluir que ya desde finales del siglo pasado existía un consenso en afirmar que las identidades y las culturas se construyen, no existen desde siempre ni son inmutables, y que se construyen a partir de la diferencia, de la presencia de otro, en relaciones de pasividad o resistencia, de dominio y sumisión. En palabras de Bhabha, "la cultura se construye y la tradición se inventa" (Bhabha, 1993: 190-191).

La consecuencia visible de estas transformaciones, que a su vez son causa o resultado de hechos históricos y sociales, como la independencia de las antiguas colonias europeas, o el surgimiento de países emergentes con cierto poder económico, o las conquistas de las mujeres en distintos campos, es que los grupos considerados marginales o minoritarios, nacionales, raciales, sociales o sexuales, en posiciones de abandono o sometimiento, han empezado a contar su propia historia que había sido distorsionada, manipulada o silenciada por la cultura dominante.

En este proceso de construcción de culturas e identidades la producción literaria de un país, grupo o nación, juega un papel esencial y transformador. La literatura refleja 
y pone en circulación no sólo géneros, estructuras o formas literarias, sino temas, imágenes, escenarios, que pueden estar en relación de sumisión o resistencia con la cultura dominante. De modo semejante, la traducción desempeña un papel crucial en mantener o desmantelar mitos, historias, imágenes de una cultura específica al pasar a la cultura y lengua receptora. De ahí la creciente importancia que han adquirido los estudios de traducción con un giro cultural.

Es cierto que muchos, particularmente los poscolonialistas, consideran a la traducción como un instrumento que ha sido utilizado por los conquistadores para perpetuar las relaciones de dominación, así como para extinguir culturas minoritarias o lenguas vernáculas, en virtud de que los que están en el poder determinan qué, cuándo y cómo se traduce. ${ }^{1}$

No obstante, desde la última década del siglo pasado, y con más intensidad en este siglo XXI, los teóricos de la traducción han insistido en que los estudios de traducción son un vehículo ideal para investigar las relaciones de cambio y transformación que se dan entre culturas, una relación que se caracteriza por la tensión entre lenguas y culturas diferentes y de la que surge un nuevo lenguaje, un nuevo espacio, una nueva cultura. Pero no sólo eso. La traducción, entendida no como una mera transferencia lingüística, sino como dice Barbara Godard, "la continuación de un proceso de creación de significado, la circulación de significado dentro de una red contingente de textos y discursos sociales"2), puede contribuir a poner en circulación en otras culturas las identidades construidas por escritores que rechazan las imágenes estereotipadas impuestas por las culturas dominantes. Es en este sentido que Sherry Simon afirma que la traducción es desestabilizadora y agrega que no sólo es una metáfora para representar el intercambio cultural sino el proceso mismo de construcción de nuevas culturas, lenguajes e identidades (1996).

A partir de las nociones de "otredad" y "diferencia", "resistencia a la hegemonía" y "construcción de identidades y culturas plurales", me propongo examinar la obra de algunos poetas irlandeses y escoceses nacidos en el siglo pasado que reflejan estas preocupaciones en su práctica de escritura. Si bien es cierto que Irlanda y Escocia no se perciben al mismo nivel que las antiguas colonias británicas, por haber sido o ser aún, bajo distintas modalidades políticas, integrantes del Reino Unido de la Gran Bretaña, no es menos cierto que ambos países han sufrido por siglos la dominación inglesa que en ciertos momentos casi extinguió sus lenguas vernáculas y oscureció o devaluó sus respectivas culturas nacionales. Las luchas por su autonomía o su independencia, el rescate de sus antiguas tradiciones y lenguas vernáculas, así como sus intentos por construir una identidad política y cultural distinta a la inglesa, han sido una constante a lo largo de su historia, particularmente desde fines del siglo XIX a la fecha.

El acercamiento a la producción poética de Irlanda y Escocia en el siglo XX nos permite constatar la importancia y singularidad de estas tradiciones no sólo en lo

\footnotetext{
${ }^{1}$ Ver Nair Anaya, 2009-2010: 261.

${ }^{2}$ Citada por Simon, 1996: 24.
} 
literario sino en lo político. De la misma manera, nos revela la presencia abrumadora de mujeres poetas que exploran la dolorosa realidad de su país desde su perspectiva personal y paralelamente afirman su condición de mujeres que dan voz a la experiencia femenina dentro de una tradición literaria que antes las había silenciado.

Como explica José Juan Dávila en el Prólogo a Una lengua injertada. Poesía irlandesa del siglo XX (Cruz, 2003: 9-10), Irlanda ha sufrido a través de su historia rebeliones sangrientas, luchas independentistas y guerras fratricidas por motivos religiosos y políticos. En un pasado anterior al dominio de los ingleses en el siglo XIII, el gaélico era la lengua vernácula y el bardo gaélico ocupaba un lugar privilegiado en la creación y difusión de leyendas y mitos celtas. Pero poco a poco los conquistadores ingleses fueron imponiendo su idioma y ya en el siglo XVII llevaron al gaélico o irlandés a una extinción casi total como lengua vernácula y con ello a una tradición y una cultura. A finales del siglo XVIII se dio un breve renacimiento de inspiración celta, pero fue durante la transición del siglo XIX al XX que muchos escritores se dieron a la tarea de rescatar y vivificar antiguas historias, leyendas y tradiciones irlandesas, en lo que fue conocido como el Irish Literary Revival, en el que destacan William Butler Yeats y James Joyce. Estos escritores contribuyeron así a la construcción de un pasado, una Historia (con mayúsculas) de tintes heroicos y míticos y a la creación de una identidad nacional con el fin de contrarrestar la influencia de la cultura invasora.

Sin embargo, a partir del último cuarto del siglo pasado los escritores, hombres y mujeres, cuestionaron ese pasado idealizado y nostálgico, representado en la poesía de Patrick Kavanagh, entre otros, y se plantearon en términos más radicales las cuestiones de identidad y de pertenencia nacional, reformulando o adecuando antiguos mitos y leyendas a su propia experiencia contemporánea. El crítico Gregory A. Schirmer considera este periodo de asombrosa y abundante producción literaria como un segundo renacimiento literario equiparable al Irish Literary Revival de principios de siglo Xx (1998: 352). Los poetas optaron por explorar los conflictos y preocupaciones políticos y sociales de la Irlanda contemporánea, construyendo una identidad basada en una realidad actual y se propusieron desarrollar e innovar una tradición poética propia, distinta de la inglesa, que entrara en diálogo con las de otras naciones. Algunos siguieron escribiendo en inglés y otros encontraron su lenguaje poético fuera del inglés e incluso decidieron escribir sólo en gaélico para recuperar sus raíces y subrayar su identidad. No obstante, no deja de ser irónico que, a pesar de todo, la mayoría de ellos escriban con gran maestría en la lengua inglesa, "una lengua injertada" que les fue impuesta, o que los poetas que escriben en lenguas vernáculas sean traducidos al inglés por sus colegas a fin de alcanzar mayor difusión. En parte esto explica por qué Schirmer afirma en su estudio que la poesía irlandesa contemporánea no responde sólo a las cuestiones sociopolíticas actuales, sino que surge de una interacción "compleja, con frecuencia problemática, pero siempre productiva, con su propia historia" (1988: 352).

Uno de los temas recurrentes, expresados con gran intensidad emocional por poetas irlandeses, es la imposición forzada de una cultura y una lengua extranjera, con la 
consecuente pérdida de su lengua vernácula y de sus raíces, o la angustia del exilio y de sentirse desplazados al encontrarse fuera de Irlanda obligados a convivir con la lengua y la cultura inglesas. John Montague y Eavan Boland destacan por el profundo impacto de sus poemas dedicados a explorar estos conflictos.

John Montague (1929) es uno de los poetas vivos más importantes de Irlanda, nacido en Brooklyn y que ha pasado su vida entre Estados Unidos, Irlanda y Francia, pero evocando siempre el paisaje y las leyendas del campo irlandés, por lo que sus críticos lo han llamado un escritor global-regional. Su poema titulado "The Grafted Tongue"” expresa con la metáfora del título la dolorosa experiencia de verse forzado a aprender la lengua del opresor y explora, en un tono elegiaco mezclado con cierta amargura, el gradual alejamiento y pérdida de la propia identidad encarnada en un pasado rural de dimensión mítica, así como el peligro de que la lengua y cultura originarias se desvanezcan para las nuevas generaciones:

\section{A GRAFTED TONGUE}

(Dumb, bloodied, the severed head now chokes to speak another tongue -

As in a long suppressed dream, some stuttering garbled ordeal of my own)

An Irish child weeps at school repeating its English. After each mistake

The master gouges another mark on the tally stick hung about its neck

Like a bell on a cow, a hobble on a straying goat. To slur and stumble

${ }^{3}$ Los poemas citados en esta sección han sido tomados de Una lengua injertada. Poesía irlandesa del siglo XX, ed. Eva Cruz Yáñez, 2003. 
In shame

the altered syllables

of your own name;

to stray sadly home

And find

the turf cured width

of your parent's hearth

growing slowly alien:

In cabin

and field, they still

speak the old tongue.

you may greet no one.

To grow

a second tongue, as

harsh a humiliation

as twice to be born.

Decades later

that child's grandchild's

speech stumbles over lost

syllables of an old order.

Años más tarde, Eavan Boland (1944), una de las poetas de mayor prestigio dentro y fuera de Irlanda, habla en su poema "An Irish Childhood in England: 1951", de la angustia de encontrarse en el país que la ha despojado de sus raíces y del conflicto y la humillación que le produce enfrentarse a una cultura y una lengua que le son ajenas.

AN IRISH CHILDHOOD IN ENGLAND: 1951

The bickering of vowels on the buses, the clicking thumbs and the big hips of the navy-skirted ticket collectors with their crooked seams brought it home to me:

Exile. Ration-book pudding

Bowls of dripping and the fixed smile of the school pianist playing 'I olanthe',

'Land of Hope and Glory' and 'John Peel'.

I didn't know what to hold, to keep.

At night, filled with some malaise of love for what I'd never known I had, I fell asleep and let the moment pass.

The passing moment has become a night of clipped shadows, freshly painted houses, 
the garden eddying in dark and heat, my children half-awake, half-asleep.

Airless, humid dark. Leaf-noise.

The stirrings of a garden before rain. A hint of storm behind the rising moon.

We are what we have chosen. Did I choose to? -

In a strange city, in another country, on nights in a North-facing bedroom, waiting for the sleep that never did restore me as I'd hoped to what I'd lost -

let the world I knew become the space between the words that I had by heart and all the other speech that always was becoming the language of the country that I came to in nineteen-fifty-one: barely-gelled, a freckled six-year-old, overdressed and sick on the plane when all of England to an Irish child

was nothing more than what you'd lost and how: was the teacher in the London convent who When I produced 'I amn't' in the classroom turned and said - 'you're not in Ireland now'.

Boland vuelve al tema una y otra vez, como en "A Beautiful Speech", donde reconoce la belleza de la lengua inglesa que aprendió a dominar, "esas frases satinadas" que ya no puede abandonar, sólo para darse cuenta de que el odio y la ambición territorial se ocultan detrás de ese bello lenguaje, en tanto las entrañables palabras que definen su ser irlandesa se desvanecen en el aire otoñal del país extranjero. El poema expresa vívidamente lo que Sherry Simon describe como "the dividedness of identity, the ongoing — and never complete negotiations - between the mother tongue and the other tongue" (1996: 166).

\author{
A BEAUTIFUL SPEECH \\ In my last year in College \\ I set out \\ to write an essay on \\ the Art of Rhetoric. I had yet to find \\ the country already lost to me \\ in song and figure as I scribbled down \\ names for sweet euphony \\ and safe digression.
}


And when I came to the word insinuate

I saw that language could writhe and creep

and the lore of snakes

which I had learned as a child not to fear -

because the Saint had sent them out of Ireland -

came nearer.

Chiasmus. Litotes. Periphrasis. Old

induces and agents of persuasion. How

I remember them in that room where

a girl is writing at a desk with

dusk already in

the streets outside. I can see her. I could say to her -

we will live, we have lived

where language is concealed. Is perilous.

We will be - we have been - citizens

of its hiding place. But it is too late

to shut the book of satin phrases,

to refuse to enter

an evening bitter with peat smoke, where newspaper sellers shout headlines

and friends call out their farewells in

a city of whispers

and interiors where

the dear vowels

Irish Ireland ours are

absorbed into Autumn air,

are out of earshot in the distances

we are stepping into where we never

imagine words such as hate

and territory and the like - unbanished still

as they always would be - wait

and are waiting under

beautiful speech. To strike.

La difícil y problemática relación política de Irlanda con el Reino Unido, marcada por episodios de sublevación y sumisión, a veces simultáneos, se condensa en el poema titulado "An Act of Union”, del poeta irlandés Seamus Heaney (1939), que obtuvo el Premio Nobel en 1995 y es considerado por muchos el mejor poeta irlandés en la actualidad. El poema alude al Acta de Unión 1801 que unió al Reino de la Gran Bretaña (formado entonces por Inglaterra y Escocia) y al reino de Irlanda, y constituye una metáfora de esa relación problemática a lo largo de la historia. El poeta utiliza desde 
el título imágenes que evocan el acto sexual en un contexto violento de dominación y subordinación que alude a las relaciones conflictivas y dolorosas entre las dos naciones con un profundo sentido de fatalidad:

\author{
AN ACT OF UNION \\ I \\ To-night, a first movement, a pulse, \\ As if the rain in bogland gathered head \\ To slip and flood: a bog-burst, \\ A gash breaking open the ferny bed. \\ Your back is a firm line of eastern coast \\ And arms and legs are thrown \\ Beyond your gradual hills. I caress \\ The heaving province where our past has grown. \\ I am the tall kingdom over your shoulder \\ That you would neither cajole nor ignore. \\ Conquest is a lie. I grow older \\ Conceding your half-independent shore \\ Within whose borders now my legacy \\ Culminate inexorably. \\ II \\ And I am still imperially \\ Male, leaving you with the pain, \\ The rending process in the colony, \\ The battering ram, the boom burst from within. \\ The act sprouted an obstinate fifth column \\ Whose stance is growing unilateral. \\ His heart beneath your heart is a wardrum \\ Mustering force. His parasitical \\ And ignorant little fists already \\ Beat at your borders and I know they're cocked \\ At me across the water. No treaty \\ I foresee will salve completely your tracked \\ And stretchmarked body, the big pain \\ That leaves you raw, like opened ground, again.
}

En el contexto de este segundo renacimiento literario irlandés destacan de manera sobresaliente las poetas mujeres que han logrado ubicarse dentro de la tradición literaria de Irlanda, no como musas, iconos o símbolos (como lo fue Maud Gonne para Yeats y las luchas por la independencia), sino como protagonistas de la historia y la cultura irlandesas, tal como afirma Eavan Boland: "las mujeres han pasado de ser objetos de la poesía irlandesa a ser autoras de poemas" (1995: 126).

Tres son los temas fundamentales de la poesía escrita por mujeres: la revaloración de su herencia irlandesa frente a la cultura colonizadora y opresora; la reapropiación y 
re-elaboración de mitos y leyendas para inscribir a las mujeres como protagonistas de la historia y darles voz, y el rescate de la experiencia real de las mujeres en la vida cotidiana y "la escritura del cuerpo" como materia propia de la poesía.

Eavan Boland fue de las primeras en cuestionar el lugar asignado a las mujeres en la tradición poética irlandesa y en muchos de sus poemas buscó dar vida y voz a las figuras femeninas silenciadas o petrificadas en la historia, la literatura o el mito. En "Time and Violence" expresa la queja de las mujeres que han sido congeladas en el lenguaje del mito y la poesía, privándolas de vida propia, y les devuelve la voz. El reclamo final: "make us human" encuentra eco en las reivindicaciones demandadas por las mujeres ante el mundo que las ha cosificado:

\section{TIME AND VIOLENCE}

\section{[Fragmento]}

I went nearer. They were disappearing.

Dusk had turned to night but in the airdid I imagine it? - a voice was saying:

This is what language did to us. Here is the wound, the silence, the wretchedness of tides and hillsides and stars where

we languish in a grammar of sighs, in the high-minded search for euphony, in the midnight rhetoric of poesie.

We cannot sweat here. Our skin is icy. We cannot breed here. Our wombs are empty. Help us escape youth and beauty.

Write us out of the poem. Make us human in cadences of change and mortal pain and words we can grow old and die in.

El breve poema “A Woman Painted on a Leaf” es emblemático de este empeño por dar vida a la mujer idealizada por su belleza pero petrificada en el arte:

\section{A WOMAN PAINTED ON A LEAF}

I found it among curios and silver, in the pureness of wintry light.

A woman painted on a leaf.

Fine lines drawn on a veined surface in a hand-made frame. 


\section{$214 \square$ EN BUSCA DE LA DIVERSIDAD: LA POESÍA DE IRLANDA Y ESCOCIA EN EL SIGLO XX}

This is not my face. Neither did I draw it.

A leaf falls in a garden.

The moon cools its aftermath of sap.

The pith of summer dries out in starlight.

A woman is inscribed there.

This is not death. It is the terrible suspension of life.

I want a poem

I can grow old in. I want a poem I can die in.

I want to take

this dried-out face,

as you take a starling from behind iron,

and return it to its element of air, of ending -

Influidas por las teorías feministas sobre la escritura femenina, al igual que por la obra de escritoras norteamericanas, principalmente Adrienne Rich, las poetas irlandesas como Eavan Boland, Medbh McGuckian, Paula Meehan, Eiléan Mí Chuilleanáin, Nuala Ní Dhomnaill y Rita Ann Higgins, entre otras, han incorporado a su escritura realidades que habían sido excluidas de la poesía tradicionalmente masculina, tales como su experiencia cotidiana, su cuerpo y su sexualidad, develando así un territorio inexplorado que había sido vetado por motivos históricos, religiosos o literarios.

El poema "Child Burial" de Paula Meehan (1955), en cuya obra resaltan temas intimistas sobre las difíciles relaciones de pareja, o las relaciones entre madre e hija, expresa el dolor de una madre por la pérdida de su hijo en términos que desafían no sólo las convenciones sociales y culturales, sino las leyes de la propia naturaleza. El poema resulta aún más conmovedor por lo inusitado del deseo imposible y desesperanzado de la madre.

\section{CHILD BURIAL}

Your coffin looked unreal, fancy as a wedding cake.

I chose your grave clothes with care, your favourite stripey shirt,

your blue cotton trousers.

They smelt of woodsmoke, of October, 
your own smell there too.

I chose a gansy of handspun wool,

warm and fleecy for you. It is

so cold down in the dark.

No light can reach you and teach you

the paths of wild birds,

the names of the flowers,

the fishes, the creatures.

Ignorant you must remain

of the sun and its work,

my lamb, my calf, my eaglet,

my cub, my kid, my nestling,

my suckling, my colt. I would spin

time back, take you again

within my womb, your amniotic lair,

and further spin you back

through nine waxing months

to the split seeding moment

you chose to be made flesh,

word within me.

I'd cancel the love feast

the hot night of your making,

I would travel alone

to a quiet mossy place,

you would spill from me into the earth

drop by bright red drop.

En el otro terreno de la aceptación del cuerpo y la sexualidad como materia de la poesía resulta notable la obra de Rita Ann Higgins (1955), caracterizada no sólo por el humor cáustico que combina con la crítica social, sino por una mezcla de lo erótico con lo francamente político desde una perspectiva femenina. El poema "It's Platonic" nos sorprende por la inesperada intensidad de su erotismo y la corporeidad de sus imágenes, precedidas por una frase coloquial que contradice abiertamente lo anunciado por el título. 
IT'S PLATONIC

Platonic my eye,

I yearn

for the fulness

of your tongue

making me

burst forth

pleasure after pleasure

after dark

Soaking all my dream

En lo que se refiere a Escocia y su literatura, existen paralelismos notables con Irlanda, aunque su historia y su relación política con Inglaterra han sido menos turbulentas. Sin embargo, para acercarse a la producción literaria escocesa actual es necesario ubicarla, como en el caso de Irlanda, en el contexto de los aspectos conflictivos más relevantes de la historia y la cultura escocesa: su identidad política ambivalente como una nación sin autonomía anexada al Reino Unido, largo tiempo dominada por su vecino imperial, hasta su actual condición de nación que alcanzó la "devolución" en los noventas pero no la independencia; sus experiencias alternadas como territorio subyugado o entusiasta partícipe del imperio, hasta sus reclamos de independencia total vigentes hasta el día de hoy; sus múltiples tradiciones lingüísticas en escocés, gaélico e inglés que complican la creación de una literatura nacional, y la coexistencia dentro de sus fronteras de centros urbanos de gran actividad cultural e industrial como Edimburgo y Glasgow, respectivamente, y áreas rurales y tierras vírgenes objeto de románticas leyendas en el siglo XIX.

Oscilando entre estos extremos, su literatura se ha subordinado algunas veces a los modelos y valores de la cultura dominante, y en otras se ha propuesto definir una tradición literaria propia anclada en antiguas leyendas y poemas escoceses como lo hicieron en el siglo XVIII Robert Burns y Sir Walter Scott, las figuras más prominentes del romanticismo en Escocia. El primero, considerado hasta la fecha el bardo nacional, escribió mayormente en el idioma escocés y dedicó gran parte de su vida a documentar la cultura tradicional escocesa, lo que sentó las bases para el rescate del escocés como lengua literaria. El segundo escribió baladas y novelas históricas inspiradas en el folclor escocés que celebraban un pasado heroico y glorioso en una tierra indómita.

Ambos escritores, junto con las versiones de James Macpherson de poemas gaélicos apócrifos, escritos supuestamente por Ossian, contribuyeron a formar el estereotipo moderno de la cultura escocesa asociado principalmente con las regiones salvajes de 
las Highlands, en tanto que ciertos aspectos y avíos emblemáticos de esa cultura, como el tartán, los kilts, las gaitas, las colinas y los brezos, se convirtieron en símbolos nacionales.

Los inicios del siglo XX atestiguaron un resurgimiento del nacionalismo político que dio lugar a un extraordinario movimiento literario conocido como el Renacimiento Escocés, cuya figura central inicial fue el poeta Hugh MacDiarmid (1892-1978), que proponía la reafirmación del idioma escocés como medio para crear una literatura seria, capaz de estar a la altura de la vanguardia europea y al mismo tiempo mantener su identidad. En los años treintas, Sorley MacLean (1911-1996) reclamó lo mismo para la poesía escrita en gaélico, revigorizando esa tradición poética y suscitando un renacimiento gaélico acorde con el renacimiento escocés. En contraste, el poeta Edwin Muir (1887-1959) rechazó estas posturas afirmando que Escocia sólo podía crear una literatura nacional escribiendo en inglés.

Aunque muy diversos en sus aproximaciones a la literatura y la cultura escocesa, estos tres poetas y otros de sus contemporáneos y sucesores coincidieron en su preocupación por generar una identidad basada en la realidad actual y por encontrar una voz y ubicación propias, así como en el rechazo de la nostalgia por un pasado inventado. Este renacimiento continúa hasta nuestros días y ha sido fortalecido desde el siglo pasado por la poesía pujante, vigorosa y transgresora de mujeres poetas como Carol Ann Duffy, Magi Gibson y Liz Lockhead, entre muchas otras.

En lo que se refiere a las representaciones de Escocia plasmadas en la poesía contemporánea, resulta interesante comparar la imagen creada por tres poetas en distintos momentos del siglo XX, las cuales reflejan los aspectos conflictivos de su historia y su cultura mencionados antes, así como la relación, también conflictiva, de los poetas con esas representaciones.

En el poema "Scotland 1941", ${ }_{4}^{4}$ Edwin Muir (1887-1959), poeta nacido en la isla de Orkney, que insistió en usar el inglés como lengua literaria, contrasta la antigua nobleza de Escocia con su destrucción como nación debido a divisiones internas y dogmas religiosos. En él rechaza vehementemente las visiones idealizadas y artificiales de una Escocia gloriosa creadas por Burns y Scott y las contrapone a lo que él considera un pasado auténtico anclado en la unidad de tribus y familias, pero su conclusión es amarga:

\section{SCOTLAND 1941}

We were a tribe, a family, a people.

Wallace and Bruce guard now a painted field,

And all may read the folio of our fable,

Peruse the sword, the sceptre and the shield.

A simple sky roofed in that rustic day,

\footnotetext{
${ }^{4}$ Los poemas de esta sección están tomados de Cardos y lluvia: poesía escocesa contemporánea, ed. Mario Murgia (en prensa).
} 


\section{$218 \square$ EN BUSCA DE LA DIVERSIDAD: LA POESÍA DE IRLANDA Y ESCOCIA EN EL SIGLO XX}

The busy corn-fields and the haunted holms, The green road winding up the ferny brae.

But Knox and Melville clapped their preaching palms

And bundled all the harvesters away,

Hoodicrow Peden in the blighted corn

Hacked with his rusty beak the starving haulms.

Out of that desolation we were born.

Courage beyond the point and obdurate pride

Made us a nation, robbed us of a nation.

Defiance absolute and myriad-eyed

That could not pluck the palm plucked our damnation.

We with such courage and the bitter wit

To fell the ancient oak of loyalty,

And strip the peopled hill and altar bare,

And crush the poet with an iron text,

How could we read our souls and learn to be?

Here a dull drove of faces harsh and vexed,

We watch our cities burning in their pit,

To salve our souls grinding dull lucre out,

We, fanatics of the frustrate and the half,

Who once set Purgatory Hill in doubt.

Now smoke and dearth and money everywhere,

Mean heirlooms of each fainter generation,

And mummied housegods in their musty niches,

Burns and Scott, sham bards of a sham nation,

And spiritual defeat wrapped warm in riches,

No pride but pride of pelf. Long since the young

Fought in great bloody battles to carve out

This towering pulpit of the Golden Calf,

Montrose, Mackail, Argyle, perverse and brave,

Twisted the stream, unhooped the ancestral hill.

Never had Dee or Don or Yarrow or Till

Huddled such thriftless honour in a grave.

Such wasted bravery idle as a song,

Such hard-won ill might prove Time's verdict wrong,

And melt to pity the annalist's iron tongue.

Sorley MacLean (1911) es uno de los poetas escoceses de estatura internacional y uno de los más distinguidos poetas gaélicos. En su poesía aborda temas como el amor, la injusticia y el sufrimiento, acontecimientos históricos que sacudieron a Europa en el siglo pasado, así como hechos dolorosos en la historia de Escocia que funde con sus propias inquietudes personales. El poema "Hallaig" es una reflexión sobre la naturaleza del tiempo, simbolizado por el ciervo, y los efectos dolorosos de las 
Clearances, ${ }^{5}$ que dejaron un paisaje vacío poblado por los fantasmas de los expulsados. El acto de la memoria los devuelve a la vida y el poeta parece sugerir que con la muerte del ciervo, el tiempo transcurrido entre el hecho histórico y el presente desaparece, para que permanezcan vivos por siempre.

HALLAIG

'Time, the deer, is in the wood of Hallaig'

The window is nailed and boarded

through which I saw the West and my love is at the burn of Hallaig,

a birch tree, and she has always been

between Inver and Milk Hollow, here and there about Baile-chuirn:

she is a birch, a hazel,

a straight, slender young rowan.

In Screapadal of my people

where Norman and Big Hector were,

their daughters and their sons are a wood

going up beside the stream.

Proud tonight the pine cocks

crowing on the top of Cnoc an Ra,

straight their backs in the moonlight -

they are not the wood I love.

I will wait for the birch wood

until it comes up by the cairn,

until the whole ridge from Beinn na Lice

will be under its shade.

If it does not, I will go down to Hallaig,

to the Sabbath of the dead,

where the people are frequenting,

every single generation gone.

They are still in Hallaig,

MacLeans and MacLeods,

all who were the in the time of Mac Gillie Chaluim

the dead have been seen alive.

${ }^{5}$ Las Clearances (1852-1854) fueron evacuaciones masivas, con frecuencia violentas, de los trabajadores agrícolas en las Highlands, realizadas por los terratenientes para destinar la tierra al pastoreo de ganado y obtener así mayores ganancias que con los cultivos, con resultados catastróficos para los expulsados, que morían de hambre o emigraban a otras tierras. Esto significó la erradicación total de un modo de vida que había persistido por siglos. 
The men lying on the green at the end of every house that was, the girls a wood of birches, straight their backs, bent their heads.

Between the Leac and Fearns the road is under mild moss and the girls in silent bands go to Clachan as in the beginning,

and return from Clachan, from Suisnish and the land of the living; each one young and light-stepping, without the heartbreak of the tale.

From the Burn of Fearns to the raised beach that is clear in the mystery of the hills, there is only the congregation of the girls keeping up the endless walk,

coming back to Hallaig in the evening, in the dumb living twilight, filling the steep slopes, their laughter a mist in my ears,

and their beauty a film in my heart before the dimness comes on the kyles, and when the sun goes down behind Dun Cana a vehement bullet will come from the gun of Love;

and will strike the deer that goes dizzily, sniffing at the grass-grown ruined homes; his eye will freeze in the wood, his blood will not be traced while I live.

El poema de MacLean conserva un tono elegiaco por un mundo perdido. En contraste, en el último tramo del siglo XX, los poetas más jóvenes voltearon la mirada hacia una realidad política, económica y social muy distinta de la imagen estereotipada de gaitas y tartanes mencionada antes, pero todavía utilizada como marca de identidad en beneficio del mercado y el turismo. Ése es precisamente el tema de "Scotland Oh Scotland" de Magi Gibson (1953). El poema comienza como un lamento por su patria agobiada por el dogma religioso, el mercantilismo y la insensibilidad de sus políticos frente a la pobreza y el abandono, para terminar preguntando con amarga ironía si un pueblo que se identifica con símbolos vacíos y colonizado culturalmente por la televisión estadounidense puede decir que está en camino a la autodeterminación, aludiendo seguramente al referendo de 1997 sobre la creación de un Parlamento Escocés con poderes devueltos. 


\section{SCOTLAND OH SCOTLAND}

My poor small country

struggling under the weight

of so much calvinistic decency!

Scared to make love

with passion and nakedness

lest your civilised neighbours

twitch at their border curtains

and call you savages.

You chase tartan rainbows

waving lucky plastic heather,

you search for tealeaves at the bottom

of a thousand whisky bottles

to convince yourselves

there is a future.

While somewhere deep below

an outward show

of growing confidence

of MSPs and Scottish Parliament, your underbelly churns and growls

your prisons overflow with suicides and wasted lives,

your kids kick burst dreams at ever-moving goalposts

on graffiti-splattered housing schemes,

and your old folk freeze alone

watching Win A Million on flickering TV screens.

And still - to trawl those tourists in,

those silver-dollar-darlings,

you package up your sense of nationhood

in shortbread tins, in haggis skins,

in cozy tartan rugs, in highland toffee bars,

in football teams, in bull-necked rugby stars -

while behind this pseudo-culture kitsch and keech

you try to hide the awful truth

that no-one dares to utter -

you are the lion rampant

that whimpers

and never ventures from its den -

the David that never leaves his bed

to face Goliath with his stone and sling -

beaten before you begin,

a purple-faced thistle full of pricks

in ginger wigs and tartan tammies 
crying F-R-E-E-D-O-M

in cinemas and city streets and pubs

crying in your nightmares for your mammies.

Oh my sad, sad people who think that Demo Crassi

is the latest Baywatch Bimbo, who sit in living rooms and lounges

staring at Sky while your seas are poisoned,

your food is modified, your intellect is stultified -

and in your towns and villages your kids go chasing dragons

and their young dreams die -

how dare you have the brass effrontery

to say you're on the way to self-determination?

How dare you have the gall

to claim your re-birth as a nation?

Por último, quiero referirme a la poesía escrita por mujeres que, como sus colegas irlandesas y muchas otras en el mundo contemporáneo, han decidido re-construir a las mujeres que figuran en los mitos y la historia desde su perspectiva femenina y hablar de su propia experiencia del cuerpo rechazando todo convencionalismo.

Elma Mitchell (1919-2000) es quizá una de las primeras en presentar una visión de mujeres míticas humanizadas con sutil humor e ironía. En su obra logra vincular las minucias aparentemente triviales de la vida doméstica con preocupaciones humanas de gran trascendencia. En "The Death of Adam" va más allá del relato bíblico para imaginar y dar voz a las inquietudes e interrogantes que asaltan a una Eva envejecida que observa el colapso físico y mental de Adán hasta su muerte, y se pregunta si no habrá para ella una manera distinta, femenina, más adecuada de desaparecer.

\section{THE DEATH OF ADAM}

I saw it coming,

The cold.

It must have been coming on a long time.

Ever since I'd known him.

Not surprising, really,

With him come up from the dust

And me from the bone.

Still, it was odd,

Watching it actually happen.

Everything sags; did you know?

I didn't know.

Teeth fall out, and then the face falls in.

Skin 
Withers and wrinkles and shrivels like an apple

(Yes, like an apple)

And the top of the skull

(Where the hair and the brains keep complicated house together)

Becomes

Plain, smooth, simple,

Unoccupied by anything.

And he couldn't walk at all, nor talk at all

(We had to stop arguing about whose fault it was)

And the sun made his eyes hurt

And he had to leave the world that belonged to him

And the animals he'd given a name to

And the wife that was part of him,

To become a kind of collapse,

A remnant, something remembered,

Not all there any more.

He was always first at everything

And now

The first man ever to be dead.

Perhaps, as gardeners,

We should have learned from the leaves

What it means to be deciduous.

Will it always be just like this

For the rest of us?

Or must I look forward

To a separate, feminine, suitable

Method of disappearance?

Middle-aged, but still naked

To man-stare and God-stare

Covering myself up with my hands and my long grey hair,

Breasts falling like apples

And the small pool of darkness

Inside me

Gone dry?

Magi Gibson (1953) ha recibido varios premios de poesía y en 2009 fue nombrada la primera Makar (poeta laureada) de la ciudad de Stirling en casi quinientos años. Es una poeta transgresora dotada de un agudo sentido del sarcasmo y la ironía, que en la figura de sus personajes femeninos se rebela ante las normas y exigencias establecidas para las mujeres, ya sea por la religión, la sociedad, el mercado o la moda. "Wild Women of a Certain Age" se convirtió rápidamente en una especie de himno para muchas mujeres maduras, debido a que reivindica su derecho a liberarse de la esclavitud a los estereotipos de juventud, belleza y esbeltez que impone una sociedad de consumo y revalora las experiencias gozosas vividas a través del cuerpo a lo largo de la vida. 


\section{WILD WOMEN OF A CERTAIN AGE}

My sisters, the time has come

to let your hair grow long and wild and grey,

to cast away the heated rollers and the tongs.

So when the moon is nine months full

let us meet out on our lawns,

let us burn our diet sheets,

let us pound our bathroom scales

to heaps of rusting springs.

Let us shred our measuring tapes,

our Firmer Buttocks videos.

Let us burn an effigy of Cher.

Let us tip our eye creams down the pan.

Let us revel in our pink plump ripeness.

Let us wear our stretch marks like shining honours.

Let us celebrate ourselves - because we can.

For we have bodies that have loved.

We have bodies that have lived.

Mouths that have savoured cheese and meat

and dribbled over chocolate and fruit,

tongues that have tasted good and evil,

lips that have sipped fine wines,

fingers that have stroked...

We have been the carriers of babes.

Our bellies have swollen with drumlin curves, our breasts have hung like ripened fruit, our teeth have bitten skin and threads.

We have swallowed bitter pills.

We have known dark bloodstains on our hands.

We have been the carriers of laughter and of pain, the healers of our children's ills. We have lain

below the stars. We have lain below our men.

Yes, sisters, now the time has come

to claim our bodies for ourselves.

For in our silver hair, our well-filled thighs, in those laughter lines that crowd our eyes we live, we are alive. 
Obras citadas

ANAYA, Nair. 2009-2010. "La traducción y el otro. El acto (invisible) de traducir y los procesos de colonización”. Anuario de Letras Modernas, vol. 15. México: UNAM, FFL. Pp. 261-273.

BASSNetT, Susan y André LefeVere. 1998. Constructing Cultures. Essays on Literary Translation. Clevedon: Multilingual Matters.

BhabHa, Homi K. 1993. "The Postcolonial and the Postmodern: The Question of Agency". The Cultural Studies Reader. Ed. Simon DuRING. Londres / Nueva York: Routledge.

Boland, Eavan. 1995. Object Lessons. The Life of the Woman and the Poet in Our Time. Nueva York / Londres: W. W. Norton \& Company.

CruZ, Eva, ed. 2003. Una lengua injertada. Poesía irlandesa del siglo XX. Trad. Seminario Permanente de Traducción Literaria, UNAM, FFL. México: UNAM, Dirección de Literatura.

DÁVILA, José Juan. 2003. Prólogo: "Una mirada a la poesía irlandesa del siglo XX”. Una lengua injertada. Poesía irlandesa del siglo XX. México: UNAM, Coordinación de Difusión Cultural, Dirección de Literatura. Pp. 9-14.

DurING, Simon, ed. 1993. Introducción. The Cultural Studies Reader. Londres / Nueva York: Routledge. Pp. 1-28.

EAgLETON Terry, ed. 2001. La idea de cultura. Una mirada política sobre los conflictos culturales. Trad. Ramón José DEL CASTILLO. Barcelona: Paidós.

Murgia, Mario, ed. [En prensa]. Cardos y lluvia: poesía escocesa contemporánea. Trad. Seminario Permanente de Traducción Literaria, UNAM, FFL. México: UNAM, Dirección de Literatura.

Schrimer, Gregory A. 1998. Out of What Began. A History of Irish Poetry in English. Ithaca / Londres: Cornell University Press.

SimON, Sherry. 1996. Gender in Translations. Cultural Identity and the Politics of Transmission. Londres / Nueva York: Routledge. 